fruit, vegetables, and live stock now conveyed by road, but also such things as coal and cotton. Of the $4,000,000$ bales of cotton grown in Texas in $1930,1,200,000$ reached the ports by motor vehicles. But severe as is the inroad made on the freight traffic of the railroads by motor wagons, still more severe is that due to the private motor car and the motor buses. In 1920 the passenger earnings of American railroads were nearly 21 per cent of their total operating revenues, but in 1930 this figure had fallen to 13.8 per cent, and the showing for 1931 was even worse.

Added to the competition from the roads is that due to the carriers by water, for inland and coastwise traffic. At the time the Panama Canal Act of 1912 was passed, several railroad companies had steamship lines on the Great Lakes and on the Pacific and Atlantic seaboards. By that Act, however, the companies were prohibited the use of the Canal for vessels owned by them, and other restrictions were placed on their maritime activities. At the close of the War, too, the United States possessed a large surplus of ships. Many of these were sold at a low figure and placed in service, while the Government itself entered the business of inland water transportation. The schemes have never paid their way, and, says Dr. Johnson, "it is hard to justify the continuance of business operation on this basis by the Government in competition with private enterprise".

Traffic has not only been leaving the rails for the roads and waterways, but also for underground pipelines for distributing oil, natural gas, and gasoline. Formerly nearly all petroleum was sent by freight cars, and it involved a large tonnage. In 1929 only $4 \cdot 5$ per cent of the production was transported by rail. There are now 100,000 miles of crude oil pipelines in the United States, 65,000 miles of pipelines for the distribution of natural gas, and in 1931 there were also 3800 miles of gasoline pipelines. The rapid increase in the use of oil and gas has had a marked effect on the coal output of the country, and it has been estimated that in 1929 natural gas was substituted for about $77,500,000$ tons of bituminous coal.

As to civil aviation in the United States, a recent return shows that American air transport companies now operate over routes with a total mileage of 51,000 miles, and the machines cover a total distance of 150,000 miles every twenty-four hours.

The problem of co-ordinating the great and varied transportation services of the United States, it will thus be seen, is a very complex one. It is one dealt with by Dr. Johnson and Mr. Wilson in their respective papers, both of which are worthy of the attention of the authorities in Great Britain. In reviewing the constructive and corrective measures required, Dr. Johnson mentions the reduction of unprofitable train services, the operation by the railways of both passenger and freight motor services, a reduction in the competition among the railways themselves, the consolidation or grouping of the railways into a limited number of systems, the co-ordination of rail, road, water, and air services, and the regulation of all transport agencies by the Government, according to a sound and equitable national policy. What co-ordination means and how it can be effected is dealt with fully by Mr. Wilson, who says: "The trend towards coordination has proceeded to the point that we can predict that the great railroads, steamship companies, electric railways, and other specialised carriers will tend to become transportation companies... offering a variety of transportation services to shippers and travellers that will supply the needs and fit the pocket-books of their patrons".

\title{
Polar Lights *
}

\section{By Prof. S. Chapman, F.R.S.}

$\mathrm{M}^{\mathrm{A}}$ ANY of the principal facts concerning the polar lights, or aurora, have long been known. For example, John Dalton, the great chemist, who observed the lights carefully for many years, and thought deeply upon them, was well aware of their close connexion with the earth's magnetism : as shown by their occurrence mainly in regions centred at the magnetic (rather than the geographical) poles, by their tendency to be extended in the direction transverse to the magnetic meridian, by the near agreement between the direction of auroral rays and the local direction of a freely poised magnetised needle, and by their parallelism, in time of occurrence and in intensity, with magnetic disturbances or storms. His ideas as to their height, on which Cavendish had made careful measurements, were also in general accord with modern determinations.

Modern observations of auroræ have advanced

* Substance of a lecture delivered at the annual general meeting of the British Science Guild on May 25.

No. 3266, VoL. 129] our knowledge chiefly by establishing the height and situation with incontrovertible accuracy, by the methods of Størmer and his followers ; and by the interpretation of the beautifully coloured auroral light, with the aid of the spectroscope and the great body of modern knowledge concerning atomic and molecular spectra.

Much remains to be done before the full fruits of the study of the auroral spectrum are garnered, but two main facts are established: a large part of the spectrum consists of bands due to singly ionised nitrogen molecules, while the famous green line, a standing challenge to spectroscopists for many decades, has been shown by McLennan to be emitted by neutral atomic oxygen; he, his colleagues, and others have traced the line in detail to its source in a particular transition occurring in the oxygen atom. Through the initiative of another active investigator of the auroral spectrum, Vegard, the Rockefeller Foundation has instituted an auroral observatory, maintained by the Norwegian Govern- 
ment, at Troms $\varnothing$; special attention will be devoted at this well-equipped and favourably situated observatory to this side of auroral research. A further remarkable observational discovery concerning the aurora, due to Størmer, is the recognition that the specially high auroræ, sometimes seen in the west after sunset, or in the east before sunrise, are in the part of the atmosphere, beyond the earth's shadow, still traversed by the sun's rays.

On the side of theory, the advances have been of comparatively recent date. Birkeland laid the foundations, by his speculations and experiments, on which Størmer has reared a great mathematical superstructure, developing the hypothesis that the aurora is due to electrically charged particles from the sun; these are deflected by the earth's maignetic field towards the polar regions, thus explaining the geographical incidence of auroræ. Størmer has deduced from this hypothesis the existence of the two auroral zones, and many other observed features of the aurora. But valuable and successful as the present theory is, it suffers, as Schuster indicated, from a great and deep-lying defect. Of the forces which guide the particles, the theory considers only the electromagnetic, whereas there will also be important electrostatic forces, which the theory ignores; the latter arise from the mutual influence of the particles, which must be partly positive and partly negative, in nearly equal numbers. A new theory must be built up, taking both sets of forces into account; this promises to be exceptionally difficult, and only the merest beginning has yet been made. It is to be hoped that, in the future development of the work, much of the existing theory will find a place, being preserved in a larger structure, as has happened in many other branches of physical theory; but of this it is still too soon to judge.

At the present time we stand, it is hoped, on the eve of a further advance in the observation and theory of the aurora, and of its associated phenomenon, magnetic disturbance. Expeditions are now proceeding to take up their stations at many points in and near the arctic circle, in connexion with the new International Polar Year for scientific research on magnetism, auroræ, and meteorology. With modern instruments and methods, a great extension of the knowledge afforded by the first Polar Year, 1882-83, may confidently be looked for. The British magnetic and meteorological expedition, led by Mr. J. M. Stagg, left for Fort Rae early in May; among other items of its programme is included the determination of auroral heights, from two stations connected by cable or radio. Another British expedition, under Prof. E. V. Appleton, will leave shortly for Tromsø, to determine, by radio methods, the amount, distribution, and changes of ionisation near the auroral zone ; its results should be of extraordinary interest and value for both auroral and magnetic research.

\section{Obituary}

Sir Thomas Legge, C.B.E.

$\mathrm{T}^{\mathrm{H}}$ HE death on May 7 of Sir Thomas Morrison Legge, late Senior Medical Inspector of Factories, deserves more than a formal note; for his official record in this capacity was coterminous with the chief reforms in factory hygiene which have occurred. In securing these he played an essential part.

Legge was the son of a distinguished Chinese scholar. After taking his degree with honours at Oxford, he investigated public health conditions in European countries, and described their municipal administration in a volume which may still be referred to with advantage. After serving as secretary of the Royal Commission on Tubereulosis, 1896-98, he worked in public health in Brighton, and afterwards was appointed the first Medical Inspector of Factories and Workshops, a post held by him for nearly thirty years. In this capacity he undertook many important investigations; among others, the relation of cataract to the glare in a glass-blowing factory, the causation of nystagmus, and the origin of various other industrial conditions, in which questions of compensation arose.

Legge gave the Milroy lectures before the Royal College of Physicians on anthrax ; and some years later his distinction in industrial medicine was indicated by his receiving from the same College the Bisset Hawkins medal as a pioneer in public health. He was instrumental in securing the establishment of an official disinfecting station for wool coming from anthrax-infected countries.

Legge's life-work was largely concerned with investigations of industrial lead poisoning and with securing regulations against these risks; and the record of steadily diminishing incidence of cases of lead poisoning year by year is eloquent testimony to the success of his work and that of his colleagues. In 1921 at Geneva thirty countries, including Great Britain, had agreed to a draft Convention, under which it was intended to prohibit the use of lead paint for internal painting. In 1927 Great Britain, however, while regulating the employment of lead paint, did not make its prohibition absolute, and Legge resigned his post at the Home Office in protest, a year or two before his appointment lapsed by flux of time.

Before and after his retirement Legge did valuable work in promoting industrial hygiene, by lecturing on his subject in America and in Great Britain. He held very strongly that for medical students industrial hygiene and poisoning were left almost entirely out of the medical curriculum. He was also insistent that the psychology of the worker should be more fully studied and considered.

Throughout his life, Legge took great interest in the artistic side of the worker's work ; and outside his daily work he delighted in discovering examples of old church and other stained glass. In this subject he was, indeed, an authority, and had at one time a valuable collection. 